\title{
Towarzyszenie duchowe osobom homoseksualnym według Daniela-Ange'a
}

\author{
Spiritual Accompaniment of Homosexual Persons According to Daniel Ange
}

\author{
JAN KRZYSZTOF MICZYŃSKI \\ Katolicki Uniwersytet Lubelski Jana Pawła II \\ miczynski@kul.pl, ORCID: 0000-0003-1052-5655
}

\begin{abstract}
Streszczenie: Artykut jest teologiczno-duchowym komentarzem do publikacji Daniela-Ange'a (ur. 17 X 1932 r. w Brukseli) na temat homoseksualizmu i pomocy duchowej ludziom o skłonnościach homoseksualnych. Główne jego myśli zostały opublikowane w książce Homosexuel qui es-tu? Où vas-tu? (Homoseksualisto kim jesteś? Dokąd podażasz?) wydanej we Francji w 1992 r. Dzisiaj, kiedy dyskusja na temat tzw. „nieheteronormatywności” staje się coraz bardziej gorąca, jego myśl, oparta na wielu rozmowach i korespondencji z homoseksualistami, wydaje się bardzo istotna. Daniel-Ange proponuje pomoc tym dziewczętom i chłopcom, którzy wbrew sobie odczuwają skłonności homoseksualne, którzy czynią heroiczne wysiłki, by się im nie poddać, i marzą o normalnym życiu seksualnym. Wspomniany zakonnik postuluje, by z wielkim szacunkiem odnosić się do wszystkich potrzebujących pomocy, proponuje im duchową drogę wzrostu: 1. poznania swojej godności w Bogu; 2. odkrycia przyczyn homoseksualizmu; 3. pełniej pokoju twórczej pracy nad sobą; 4. dojrzewania w prawdziwej miłości - w Bogu. Artykuł przytacza konkretne porady duchowe Daniela-Ange’a i ukazuje je w świetle współczesnych dokumentów Kościoła.
\end{abstract}

Słowa kluczowe: homoseksualizm, kierownictwo duchowe, pomoc, orientacja, skłonności

Abstract: The article is a theological and spiritual commentary on the publication of Daniel-Ange de Maupeou d'Ableiges (born 17th October, 1932, in Brussels) on homosexuality and spiritual aid to people with homosexual inclinations. His main thoughts were published in the book Homosexuel qui es-tu? Où vas-tu? (Homosexual, Who Are You? Where Are You Going?), published in France in 1992. Today, as discussions about so-called "non-heteronormativity" become more and more heated, his thoughts, based on many conversations and correspondences with homosexuals, seem to provide crucial insight. Daniel-Ange offers to aid those girls and boys who have homosexual inclinations, in defiance of their selves, and who make heroic efforts not to give up but dream of a normal sex life. The author advocates that all those in need of aid be treated with great respect, and offers them a spiritual way of growth: (1) to know their dignity in God; (2) to discover the causes of their homosexuality; (3) to creatively work on themselves in peace; and (4) to mature in true love - in God. The article sets forth specific spiritual advice of Fr. Daniel-Ange and demonstrates it in light of contemporary Church documents.

Keywords: homosexuality, spiritual direction, aid, orientation, inclinations

Ojciec Daniel-Ange (Daniel-Ange de Maupeou d'Ableiges) jest charyzmatycznym duchownym pochodzącym z Belgii (ur. 17 X 1932 r. w Brukseli), znanym w kręgach katolickiej młodzieży jako założyciel pierwszej w Europie Międzynarodowej Szkoły Modlitwy i Ewangelizacji Jeunesse-Lumière. W ramach pracy apostolskiej odbył on 
ponad dwieście podróży do różnych krajów świata (w tym ponad dwadzieścia do Polski), głosił rekolekcje i konferencje, spotykał się z wieloma młodymi ludźmi na rozmowach oraz na modlitwie. Opublikował około siedemdziesięciu książek dotyczących życia duchowego współczesnego człowieka, napisał również na ten temat wiele artykułów ${ }^{1}$. W dniu 26 czerwca 2008 r. Senat Katolickiego Uniwersytetu Lubelskiego Jana Pawła II nadał mu - na wniosek Rady Wydziału Teologii - tytuł doktora honoris causa Katolickiego Uniwersytetu Jana Pawła II. Jako argument podano pragnienie wyrażenia szacunku i głębokiej wdzięczności za jego żywiołowe duszpasterstwo, które daje ludziom młodym nadzieję, a także ukazuje pełną Ewangelię wymagającą prawdy oraz uwalniającą miłość2.

W czasie spotkań z o. Danielem-Ange młodzież dzieliła się swoimi wielorakimi egzystencjalnymi problemami, duchowymi dylematami, także dotyczącymi kwestii homoseksualizmu. Niektóre z osób o skłonnościach homoseksualnych ${ }^{3}$ poprosiły go, by napisał jakieś słowo otuchy skierowane konkretnie do nich. Po blisko dziesięciu latach gromadzenia materiałów, prowadzenia rozmów i słuchania zwierzeń, w 1992 r. powstał tomik Homosexuel qui es-tu? Où vas-tu? (w dosłownym tłum. „Homoseksualisto, kim jesteś? Dokąd idziesz?”), który ukazał się w języku polskim w 1993 r. pod nieco zmienionym tytułem: Homoseksualizm. Czym jest? Do czego prowadzi? Autor zawarł w tej książce program duchowy dla osób homoseksualnych oraz wiele postulatów dla ich otoczenia. Tomik ma niezwykle cenną pod względem duszpasterskim formę pisanego w zaufaniu prywatnego listu. Jest on skierowany do każdego, kto przeżywa trudności w obszarze tożsamości oraz orientacji seksualnej; do tych dziewcząt i chłopców, którzy wbrew samym sobie dostrzegają u siebie skłonności homoseksualne ${ }^{4}$.

Dzisiaj, kiedy dyskusja na temat tzw. „nieheteronormatywności” staje się coraz bardziej gorąca, angażująca świat naukowy oraz często i pseudo-naukowy, wydaje się potrzebne, by przypomnieć świadectwo towarzyszenia duchowego o. Daniela-Ange osobom homoseksualnym, opisać je w sposób ,intelektualnie chłodny”, systematyczny, i na ile to możliwe - syntetyczny. Wydaje się, że takiego opracowania nikt się jeszcze dotąd nie podejmował.

1 Kłysz (red.), Prorok Światta, 5, 67. Sylwetkę duchową o. Daniela-Ange’a można poznać dzięki niedawno opublikowanej jego duchowej autobiografii: Daniel-Ange, Serviteur du Très-Beau.

2 Zob. Uchwała Senatu Katolickiego Uniwersytetu Lubelskiego, 5.

3 Warto zwrócić tu uwagę na fakt, że termin „skłonność homoseksualna” (użyty np. w KKK 2358; wł. tendenze omosessuali) nie występuje w Międzynarodowej Statystycznej Klasyfikacji Chorób i Problemów Zdrowotnych ICD. Przez wyrażenie „skłonność homoseksualna” rozumie się tu głównie tzw. homoseksualizm egodystoniczny (niezgodny z własnym ego).

4 Zob. Daniel-Ange, Homoseksualizm, 8. Znamienne jest to, że autor nie kieruje swojej publikacji do wszystkich, którzy utożsamiają się - z różnych powodów - z homoseksualizmem, ale do tych, którzy odczuwają skłonności homoseksualne i ich nie akceptują (zob. ibidem, 8-9). Tematykę ludzkiej seksualności Daniel-Ange podejmuje również w innych swoich książkach, m.in.: Twoje ciało stworzone dla miłości; Twoje ciało stworzone dla życia; Eblouissante sexualité, pourquoi te dynamiter? 


\section{Z miłosierną miłością ku człowiekowi}

Mając na celu pomoc duchową osobom odczuwającym pragnienia homoseksualne, Daniel-Ange wskazuje, że poważnym problemem jest już sama atmosfera utworzona wokół tego tematu. Jest ona często na tyle niezdrowa, że ludzie o wspomnianych skłonnościach, szukający nadziei w Bogu, w Kościele, przeżywają nieraz całkowite wręcz załamanie. Główną przyczyną tego jest częste doświadczanie wyśmiewania, zwalczania, potępiania czy nieustannej krytyki. Dlatego też potrzebne jest przypomnienie możliwie największej liczbie osób, a szczególnie ludziom Kościoła, że każdego człowieka należy umieć przygarnąć, wspomóc, wewnętrznie odbudować, podtrzymać na duchu, objąć troską, zrozumieć i kochać, co oczywiście nie oznacza jednocześnie popierania, pochwalania czy też uznawania jakichś złych czynów ${ }^{5}$. Autor oczywiście nie usprawiedliwia żadnego grzechu.

W tym kontekście przychodzi na myśl pytanie: kto jest otwarty na taką pomoc? Czy wszyscy? Autor wyrożnia trzy grupy pośrod osob powiązanych na rożny sposob $\mathrm{z}$ homoseksualizmem ${ }^{6}$ :

- dziewczęta i chłopcy odczuwający wbrew sobie skłonności homoseksualne, czyniący heroiczne wysiłki, by się im nie poddać - marzący o normalnym życiu seksualnym;

- ludzie mający normalne stosunki heteroseksualne, a decydujący się na homoseksualizm dobrowolnie, przez perwersję, dla szukania nowych doznań (często na starość);

- ci, którzy wychwalają homoseksualizm, programują go (czasem już od najwcześniejszych lat życia), tworzą tzw. „nową kulturę”, nowoczesny światopogląd (a którzy mogą być jednocześnie sprawcami - jak pisze omawiany autor - zbrodni niezamierzonych: wielu ofiar AIDS itp.).

Ojciec Daniel-Ange adresuje swoje duchowe rady do pierwszej grupy ludzi. Tę grupę broni szczególnie, kierując do wszystkich osób heteroseksualnych apel o zrozumienie i postawę miłosiernej miłości wobec tych, którzy przeżywają swój homoseksualizm jako problem. Nie wolno bowiem utożsamiać osoby odczuwającej skłonności homoseksualne ze swego rodzaju stereotypową „etykietką” o homoseksualistach (np. że wszyscy są pederastami, gwałcicielami, przestępcami, osobami zdeprawowanymi bądź chorymi psychicznie), prowokującą wyszydzenie

\footnotetext{
Daniel-Ange, Homoseksualizm, 6, 10.

Zob. Daniel-Ange, Homoseksualizm, 8-9. W tym trójpodziale można dostrzec podobieństwo (zapewne nie do końca zamierzone przez Daniela-Ange’a) do typologii podanej przez Richarda Cohena (Gdy twoje dziecko, 39), który sam odczuwając podobne inklinacje, poprzez pracę wewnętrzną przezwyciężył je i założył szczęśliwe małżeństwo; pisze on, że istnieją trzy typy dzieci doświadczających pociąg do tej samej płci: 1. te, które nie akceptują tych skłonności i pragną przemiany; 2. te, które nie są jeszcze zdecydowane w kwestii swojego seksualizmu; 3. te, które uważają siebie za „geja”, „lesbijkę", „biseksualistę” albo „transseksualistę" i wierzą w mit wrodzonego homoseksualizmu.
} 
i zepchnięcie na margines społeczny. Można się tu zgodzić z Danielem-Ange, że ci, którzy przeżywają swój homoseksualizm jako problem, „[...] nie mają większego pociągu do nieletnich niż większość ludzi uprawiających stosunki heteroseksualne"7; nie są więc per se większymi kryminalistami od innych, ale są jednak grzesznikami - jak inni.

To wstępne założenie belgijski zakonnik podsumowuje podstawową zasadą, którą osoba pragnąca towarzyszyć duchowo winna się bezwzględnie kierować: trzeba tak kochać homoseksualistę, by „zrozumieć, jak bardzo unieszczęśliwia go jego własny homoseksualizm" - nie za to, co robi, ale za to, kim jest jako osoba. Wówczas otwiera się droga, by pokochał on samego siebie, by odpowiedział prawdziwą i czystą miłością na dar miłości ze strony Boga oraz innych i aby odkrył, co jest w nim najpiękniejsze. Cenne jest tutaj uświadomienie sobie, że gdyby nam przyszło przeżywać to, co spotkało tego człowieka o skłonnościach homoseksualnych, prawdopodobnie bylibyśmy w podobnej sytuacji ${ }^{8}$. Ważne jest, by sam potrzebujący pragnął znaleźć towarzysza na drodze życia duchowego - osobę bardziej doświadczoną, kierownika duchowego, przewodnika - kogoś, kto jest bezgranicznie oddany Chrystusowi. Podążanie z takim „starszym bratem” albo „starszą siostrą” staje się wówczas uczestniczeniem w przyjaźni z Jezusem Chrystusem. Osoba towarzysząca winna być - mówiąc metaforycznie - „przezroczysta”, to znaczy mieć tyle serca dla potrzebujących, by oni czuli się przygarnięci przez samego Boga'.

Analizując tekst Daniela-Ange można prędko zauważyć, z jaką pokorą, wrażliwością i delikatnością stara się on kierować słowa do osób o skłonnościach homoseksualnych. Ma bowiem świadomość, że często ich stan wiąże się z bardzo bolesnymi wspomnieniami. Nie chce nikogo zranić, ale - przeciwnie - podnieść na duchu ${ }^{10}$. Osoba pomagająca musi sobie zdawać sprawę z tego, że ryzykiem zranienia obarczone jest zarówno podejmowanie tego tematu, jak i milczenie. To ostatnie może być bowiem zrozumiane jako zwykła obojętność. Przy tym wszystkim - dodatkowo potrzebne jest właściwe dobieranie słó $\mathrm{w}^{11}$, ale bez przekłamań, by być przekazicielem prawdy.

\footnotetext{
7 Por. Daniel-Ange, Homoseksualizm, 9-10; por. Komisja ds. Społecznych Episkopatu Anglii i Walii, „Wprowadzenie do opieki duszpasterskiej", 174.

8 Daniel-Ange, Homoseksualizm, 11.

9 Daniel-Ange, Homoseksualizm, 50.

10 Jest to postawa, do której wzywa Katechizm Kościoła Katolickiego (2358): „Pewna część mężczyzn i kobiet przejawia głęboko osadzone skłonności homoseksualne. Skłonność taka, obiektywnie nieuporządkowana, dla większości z nich stanowi trudne doświadczenie. Powinno się traktować te osoby z szacunkiem, współczuciem i delikatnością [...]”.

11 Por. Daniel-Ange, Homoseksualizm, 11.
} 


\section{Ku poznaniu swego serca i odnalezieniu tożsamości w Bogu}

Pomoc duchowa ludziom o skłonnościach homoseksualnych nie może pomijać problemów natury psychologicznej, a w związku z tym - w jakimś sensie - łączy się z poznaniem, w jaki sposób oni sami przeżywają tę trudną dla nich inklinację. Homoseksualizm może być niejednokrotnie problemem ponad siły: cierpieniem, upokorzeniem, powodem nieakceptacji siebie, źródłem upokorzenia, tożsamym z doświadczeniem jakiejś „nieuleczalnej choroby” czy „ułomności”, czymś wstydliwym, co trzeba ukryć jako tajemnicę. Warto delikatnie odnieść się do tego momentu, kiedy osoba homoseksualna pierwszy raz odkryła swój homoseksualizm. Mogło się to wiązać z przeżyciem głębokiego kryzysu tożsamości, z utratą wewnętrznej równowagi, z gwałtownym stawianiem sobie egzystencjalnych pytań dotyczących akceptacji ze strony środowiska, społeczeństwa, Boga i Kościoła. Brak możliwości znalezienia odpowiedzi - często z powodu wstydu i lęku, by o sobie porozmawiać z kimkolwiek mógł w osobie homoseksualnej potęgować lęk i wprowadzać ją w coraz większe poczucie samotności ${ }^{12}$.

Daniel-Ange dostrzega, że próbując uśmierzyć ten egzystencjalny ból, niektórzy wybrali drogę chirurgicznej operacji plastycznej i zmienili płeć. Liczyli, że w „nowej tożsamości”, poprzez uczynienie siebie pięknym, zdobędą uznanie i akceptację u innych. Często jednak uświadamiali sobie po pewnym czasie, że operacja tak właściwie nic w ich wnętrzu nie zmieniła, a skutkiem tego tracili jasność, kim są tak naprawdę - czy kobietą, czy mężczyzną. Powodowało to jeszcze większą udrękę, a u jej podstaw było przede wszystkim wołanie o zrozumienie, o miłość ${ }^{13}$.

Należy pomóc dotrzeć do głębi serca, bowiem wówczas, gdy osoba homoseksualna odkryje, że właściwie nie wie, kim jest, zobaczy wyraźniej, że homoseksualizm ją krzywdzi ${ }^{14}$. Daniel-Ange nie stawia tutaj żadnej tezy, nikogo nie sądzi, ale zadaje pytanie, czy przypadkiem sytuacja tych ludzi nie jest wynikiem błędów popełnionych przez innych ludzi, wadliwego funkcjonowania społeczeństwa, a homoseksualiści są jedynie ofiarami. Jak by nie było, stają oni przed fundamentalnym pytaniem, przed którym nie można uciekać: Jak dalej żyć ${ }^{15}$ ?

Na początek warto poznać - w postawie pokory - jak głęboka jest skłonność homoseksualna; może być ona bowiem:

- powierzchowna - nietrwała, związana z okresem dojrzewania płciowego (w wieku młodzieńczym), gdy płciowość dopiero jest w czasie kształtowania; utrzymuje się przez pewien czas na etapie skłonności, a następnie mija; czasem może mieć formę czasowego biseksualizmu (związanego np. z brakiem właści-

\footnotetext{
Por. Daniel-Ange, Homoseksualizm, 14.

Por. Daniel-Ange, Mai 13. Rébellion!, 49; idem, Homoseksualizm, 7, 15.

Por. Daniel-Ange, Homoseksualizm, 8.

Por. Daniel-Ange, Homoseksualizm, 15.
} 
wej edukacji, a także z przeżyciem homoseksualnym - doświadczonym umyślnie albo nieumyślnie);

- głębsza - zakorzeniona jakby „w tożsamości”, „od zawsze”, wyrażająca się w snach i pragnieniach, związana $\mathrm{z}$ doświadczeniami przeżywanymi okazjonalnie bądź w sposób długotrwały;

- zczystej ciekawości - bez rzeczywistych wewnętrznych inklinacji do tej samej płci.

$\mathrm{Na}$ tym etapie pomocy chodzi nie tyle o to, by ktoś sięgnął głęboko w samą „strukturę" swej inklinacji homoseksualnej, by odnaleźć konkretne jej przyczyny (to bowiem będzie kolejnym krokiem), ile raczej o ogólne opisanie tej swojej inklinacji. Przy tym wszystkim Daniel Ange staje na stanowisku, że homoseksualizm nie ma podłoża genetycznego ${ }^{16}$ ( $\mathrm{z}$ wyjątkiem medycznie stwierdzonego hermafrodyty$\mathrm{zmu}^{17}$ ) i dodaje, że dobrowolne i całkowite poddanie się skłonności homoseksualnej (przyzwyczajenie się do jej praktykowania) może skutkować całkowitym uzależnieniem. Skłonność ta zatem stanie się wtedy trudniejsza do wykorzeniania, a tym bardziej do kontrolowania ${ }^{18}$.

Dlatego jednym z pierwszych kroków jest przyjrzenie się sobie, by stopniowo, w Bożym świetle, odzyskać przekonanie o sensie własnego życia ${ }^{19}$. Przy tym istotne jest, by człowiek odczuwający skłonności homoseksualne nie obwiniał się za sam fakt ich posiadania. Daniel-Ange - zgodnie z nauką Kościoła - bardzo wyraźnie rozróżnia czyny od skłonności ${ }^{20}$. Te ostatnie nie są same w sobie grzechem i nie czynią człowieka automatycznie winnym. Trzeba jednak zaznaczyć, że już za swoje czyny człowiek ponosi odpowiedzialność. Nieobwinianie się za same skłonności służy utworzeniu właściwego obrazu Boga, który będąc Miłością (por. $1 \mathrm{~J}$ 4,16), kocha człowieka takim, jaki jest i jakim może się jeszcze stać, pragnie go wyzwolić i poprowadzić ku pełni życia ${ }^{21}$. Ważne jest, by również i człowiek chciał tego samego, co Bóg.

Daniel-Ange podkreśla - w duchu św. Teresy od Dzieciątka Jezus (i ukazanej przez nią tzw. „małej drogi” do świętości) - że Bóg kocha człowieka tym goręcej, im bardziej człowiek czuje się zraniony ${ }^{22}$. Bolesna przestrzeń staje się w jakimś sen-

16 Podobne stanowisko, mówiące o tym, że homoseksualizm ma podłoże psychiczne, przyjmował także kard. Karol Wojtyła (Szafrański, Homoseksualizm jako problem, 118).

17 Hermafrodytyzm (androginia, obojnactwo) to występowanie - od urodzenia u niektórych ludzi - gruczołów rozrodczych zarówno męskich, jak i żeńskich.

18 Por. Daniel-Ange, Homoseksualizm, 17.

19 Por. Daniel-Ange, Homoseksualizm, 41.

20 Por. np. Kongregacja Nauki Wiary, Persona humana, 8.

21 Por. Daniel-Ange, Homoseksualizm, 27-29. Natomiast o braku odpowiedzialności moralnej za akty homoseksualne można mówić jedynie wówczas, gdy osoba homoseksualna jest psychotykiem, gdy jest psychicznie chora; por. Szafrański, Homoseksualizm jako problem, 118.

22 Daniel-Ange stwierdza, że św. Teresa od Dzieciątka Jezus powiedziałaby współczesnemu społeczeństwu następujące słowa: „Ci, którym przykleiliście etykietkę wykolejonych, niezrównoważonych, ludzi z marginesu, psychotyków, neurotyków; ci pokrzywdzeni na wszystkie strony, ci bardzo głęboko niedorozwinięci umysłowo, wszyscy ci skrzywdzeni przez los, którzy zewsząd was otaczają, od których uciekacie, których 
sie uprzywilejowanym miejscem spotkania ze Stwórcą. Stąd też osoba doświadczająca inklinacji homoseksualnych nie może trwać w przekonaniu, że wszystko, co ją stanowi, sprowadza się jedynie do homoseksualizmu, bowiem homoseksualizm jest jednym $\mathrm{z}$ aspektów złożonej, pełnej bogactw i charyzmatów osobowości ${ }^{23}$. Popęd homoseksualny nie jest punktem konstytuującym osobę, nie stanowi i nie określa całej jej natury. Fundamentem jest zaś osobowe „ja” (o charakterze ontycznym) i obecny w niej Bóg, a także wiążąca się z tą obecnością godność dziecka Bożego. Dlatego też Daniel-Ange zwraca uwagę - niejako na marginesie - by nie używać określeń „homoseksualista”, „lesbijka”, „prostytutka”, „niepełnosprawny”, ale wyrażeń, które będą zabezpieczały ochronę godności każdego człowieka, a mianowicie: „człowiek, który doświadcza homofilii”, „człowiek, który prostytuuje się”, „człowiek, który nosi upośledzenie"24 itd. Postulat Daniela-Ange’a wydaje się bardzo słuszny, gdyż ludzki język jest nośnikiem wartości bądź antywartości, a relacje interpersonalne są często silnie warunkowane istniejącymi w społeczeństwie pojęciami, wyrażeniami, opiniami.

Osoba towarzysząca człowiekowi doświadczającemu skłonności homoseksualnych winna starać się przypominać, że ludzkie serce jest o wiele szersze niż skłonności. Jest bogatsze, kształtujące się stale, poznające nowe uczucia i przyjmujące nowe formy wyrażania siebie; człowiek bowiem stale się staje; osoba jest procesem ku wyższej egzystencji, jest wprowadzana w historię zbawienia, w Komunię Osób Bo$\dot{z ̇ y c h}^{25}$. Należy zatem zerwać $\mathrm{z}$ wizją samego siebie jako czegoś statycznego, biernego, zdeterminowanego przeszłością czy też teraźniejszością i - w wolności danej przez Boga - otworzyć się na przyszłość. Nie wolno również ulegać współczesnym poglądom, że powinno się zaakceptować skłonności homoseksualne jako coś całkowicie naturalnego, pozytywnego, „zgodnego z wolą Bożą"26.

boicie się dotknąć... a którymi pod pewnym względem wszyscy jesteście, wszyscy ci ludzie z różnymi zaburzeniami to wasi bracia. Przeszłam przez to. Wiem, co to oznacza. Upadnijcie przed nimi na kolana. Jest w nich ukryta niezmierzona tajemnica. Potrafią przeżywać tajemnicę miłości z taką intensywnością, jakiej nie podejrzewałby u nich żaden człowiek normalny" (Daniel-Ange, Uzdrowienie przez miłość, 27; por. idem, Homoseksualizm, 28).

23 Daniel-Ange, Homoseksualizm, 43.

24 Daniel-Ange, Homoseksualizm, 28-29.

25 Zob. Bartnik, Ludzka dusza, jaźń i osoba, 432-434, por. Daniel-Ange, Homoseksualizm, 28.

26 Por. Daniel-Ange, Homoseksualizm, 28-29. Przekonanie Kościoła było w tym względzie niezmienne i jednoznacznie określało akty homoseksualne (nie skłonności) jako grzeszne - peccata contram naturam. Taka właśnie ocena moralna opiera się na Objawieniu zawartym w Piśmie Świętym (zob. w Starym Testamencie: Rdz 19,4-11; Kpł 18,22 oraz 20,13; Pnp 29,22; Mdr 10,6; Iz 1,9 oraz 13,19; Jr 49,18 oraz 50,40; Am 4,11; a także w Nowym Testamencie: Mt 10,15 oraz 11,23; Łk 10,12 oraz 17,28; 2 P 2,6; Rz 1,27n; 1 Tm 1,10; Jud 1,7; Ap 2,8). Była ona formułowana w Constitutiones Apostolorum (dzieło prawdopodobnie z IV w.; zob. PL 1, 938; PG 1, 199, 978-986), na synodach: w Elwirze w 395 r., w Paryżu w 1212 r., w Reims w 1214 r.; jak również na Soborze Laterańskim III w 1139 r. Przekazywali ją: św. Klemens Aleksandryjski ( $w$ dziele Pedagog), św. Jan Chryzostom (w 19. homilii), Tertulian ( $w$ dziele De pudicitia), św. Augustyn (w Wyznaniach); papieże: Grzegorz II (w Dekretałach) i Pius V (w Konstytucji Horrendum); zob. Szafrański, Homoseksualizm jako problem, 79-88; por. Klak, Osoba homoseksualna w Kościele, 21-26. Warto tu zaznaczyć, że pojawiające się współcześnie 
Trzeba wzbudzić w człowieku żywą wiarę w Boga (by doświadczył Jego miłości), jak również nadzieję, że można coś jeszcze w życiu zmienić (by zapragnął za Nim pójść), że jest możliwe wyrwanie się z budzącej cierpienia przeszłości i bycie szczęśliwym w życiu. Towarzyszący duchowo winien mieć świadomość, że „zaistnieć na nowo" dla człowieka o skłonnościach homoseksualnych oznacza niekiedy pokonanie lęku przed utratą całej dotychczasowej przeszłości (a czasem może ktoś być od niej uzależniony), przed utratą w jakimś sensie „części samego siebie”27. Potrzebne jest zatem rozwijanie życia na poziomie ducha, rozwijanie swojej osobowości według zamysłu Boga, który uwalnia wolność człowieka i pozwala mu być prawdziwie sobą ${ }^{28}$.

Pomocą w odnalezieniu siły do zmiany - obok spojrzenia na Boga i na otrzymaną od Niego godność - jest wejrzenie w samego siebie i szczera konfrontacja z pytaniami: Czy homoseksualizm rzeczywiście rozwija, czy może raczej rodzi coraz większą gorycz, frustrację i poczucie niespełnienia? Dokąd właściwie idę, czego w życiu szukam, i czy przypadkiem nie żyję w jakimś wyimaginowanym przez siebie świecie, grając jakąś wymyśloną rolę? Daniel-Ange zachęca, by dostrzec wielką ludzką godność, że nasze serce jest zbyt wielkie, a życie zbyt krótkie, by swą miłość narażać na ciągłe zranienia w kolejnych związkach, początkowo rodzących euforię, a kończących się dramatycznym rozczarowaniem ${ }^{29}$.

Swój wewnętrzny stan można dobrze ocenić jedynie w obliczu wielkiej miłości Boga i niezbywalnej godności, którą człowiek otrzymał od Stwórcy i Zbawiciela. Spotykając się z Chrystusem - jak Danielowi-Ange’owi napisał w liście młody chłopak dotknięty homoseksualizmem - „nie można dalej utrzymywać, że homoseksualizm jest normalny" ${ }^{30}$. Daniel-Ange pragnął dopuścić do głosu przede wszystkim kogoś, kto doświadczył skłonności homoseksualnych, by z jego ust padły słowa potwierdzające naukę Kościoła, który głosi, że „akty homoseksualizmu z samej swojej wewnętrznej natury są nieuporządkowane” ${ }^{\text {”1 }}$, „są sprzeczne z prawem naturalnym; wykluczają z aktu płciowego dar życia" ${ }^{32}$. W tej perspektywie można z tym przekonaniem uczynić kolejny krok na drodze duchowego wzrostu.

sugestie, że należy przeinterpretować naukę Biblii o seksualizmie, gdyż napisana została ona w innym kontekście kulturowym, są błędne i destrukcyjne (zob. Kongregacja Nauki Wiary, Homosexualitatis problema, 4-5).

27 Por. Daniel-Ange, Homoseksualizm, 29, 31.

28 Por. Daniel-Ange, Homoseksualizm, 32.

29 Por. Daniel-Ange, Homoseksualizm, 30-31, 33.

30 Por. Daniel-Ange, Homoseksualizm, 30-31, 52.

31 Kongregacja Nauki Wiary, Persona humana, 8.

32 KKK 2357; por. Rdz 19,1-29; Rz 1,24-27; 1 Kor 6,9; 1 Tm 1,10. 


\section{Ku odnalezieniu przyczyny homoseksualizmu}

Płećc ${ }^{33}$ określa sposób istnienia i działania człowieka, realizację jego potencjalności, życiowych zadań, wypełnienia powołania. Jest zespołem cech fizycznych (genetycznych, anatomicznych, fizjologicznych), a także psychicznych i duchowych; odnosząc się do płci, mówi się o następujących kategoriach: chromosomalnej, gonadalnej, hormonalnej, germinatywnej (związanej z produkcją gamet), genitalnej, fenotypowej (dotyczącej charakterystycznych cech organizmu), somatycznej, mózgowej, psychicznej i społecznej (kulturowej) ${ }^{34}$. W prawidłowo rozwijającej się osobowości wszystkie te elementy są spójne. Jeżeli zaś z jakiegoś powodu brak jest między nimi zgodności, wówczas następuje zjawisko różnicowania płci, polegające na przyswojeniu jednej lub wielu cech należących do innej płci, czego skutkiem jest zaburzenie identyfikacji płciowej, jak również tożsamości seksualnej. Niespójność ta może sięgać swymi korzeniami wczesnych lat dzieciństwa (fazy postnatalnej) albo nawet życia prenatalnego ${ }^{35}$. Daniel-Ange jest tego świadomy, gdy pisze, że „płeć to coś ogromnie złożonego" i że powstanie oraz rozwój orientacji seksualnej może być skutkiem wielu czynników, czasem ze sobą sprzecznych, działających na człowieka niekiedy w sposób podświadomy. Autor zna teorie mówiące o tym, że źródłem homoseksualizmu jest determinacja genetyczna, atawizm, dziedziczność itp., ale ich nie podziela. Twierdzi natomiast, że te teorie są mało prawdopodobne i zwykle wcześniej czy później upadają. Dłużej utrzymują się natomiast koncepcje mówiące o przyczynie psychologicznej ${ }^{36}$.

Jako kolejny krok w towarzyszeniu duchowym osobom homoseksualnym Daniel-Ange proponuje stopniowe poznanie przyczyn, które mogły zaważyć o tychże skłonnościach. Wymienia dwie grupy czynników, ale ma jednocześnie świadomość, że mogą zaistnieć również i inne. Pierwszy zbiór stanowią przyczyny osobiste (bardziej wewnętrzne), drugi zaś przyczyny społeczne (bardziej zewnętrzne). Do przyczyn wewnętrznych zalicza między innymi: doświadczenie w dzieciństwie sodomii (ze strony osoby spokrewnionej), wychowywanie się wśród dzieci tej samej płci, nie-

33 Życie duchowe rozumiane jest w teologii jako więź osobowa człowieka z Bogiem (zob. Rz 8,9), zatem pomoc duchowa zmierza do tego, by człowiek poddał działaniu Bożemu wszystkie wymiary swojego życia (m.in. tożsamość, płciowość, orientację, popęd itd.).

34 Gałkowska-Bachanek, „Płeć”, 846

35 Por. Gałkowska-Bachanek, „Płeć”, 846.

36 Por. Daniel-Ange, Homoseksualizm, 19, 22. Choć wielu uczonych ma świadomość, że problem homoseksualizmu jest bardzo złożony, uznaje się współcześnie, że jest uwarunkowany psychologicznie; podaje się następujące koncepcje genezy homoseksualizmu: 1. teorię biologiczną (która do dziś nie została dostatecznie potwierdzona); 2. teorię wyboru (popularną w latach 50. i 60. ubiegłego wieku, dziś odżywającą w postaci poglądu, że homoseksualizm można wybrać dobrowolnie jako opcję); 3. teorię psychologiczno-społeczną (rodzinno-środowiskowa - mówiąca o tym, że prawidłowa orientacja seksualna jest owocem osobowości, sytuacji rodzinnej oraz wczesnych doświadczeń seksualnych); Klak, Osoba homoseksualna w Kościele, 12-17. 
właściwie przeżyty czas dojrzewania albo brak uświadomienia w dziedzinie seksualnej, brak w dzieciństwie i w okresie dojrzewania właściwych relacji z ojcem bądź z matką (brak miłości z ich strony i nostalgia za tym uczuciem), brak akceptacji płci ze strony rodziców (którzy pragnęli mieć dziecko płci przeciwnej), stan uzależnienia uczuciowego przekreślający duchową wolność, zjawisko inwersji w relacjach seksualnych (pragnienie pełnienia roli pasywnej - przez niektórych chłopców; albo aktywnej - przez niektóre dziewczęta), brak pozytywnych przykładów małżeństw, lęk przed nowym, odpowiedzialnością, odrzuceniem, prokreacją itp. W drugiej zaś grupie (czynniki społeczne) Daniel-Ange umieszcza następujące przyczyny: egoistyczne odrzucenie kogoś, kto jest inny (w tym również i Boga), zacieranie się różnic (np. psychologicznych) między mężczyzną i kobietą, brutalizacja życia, nieudane relacje heteroseksualne, świat propagujący homoseksualizm. Zdaje on sobie jednak sprawę z możliwości, że o skłonnościach homoseksualnych danej osoby może zadecydować kilka czynników naraz ${ }^{37}$. Zatem inklinacje te mogą mieć jedną bądź wiele przyczyn.

$\mathrm{Na}$ tym etapie bardzo ważne jest to, by nie lękać się i być z samym sobą bardzo szczerym. Trzeba jednak dodać, że nawet nie jest niezbędne doszukanie się korzeni homoseksualizmu; czasem zdarza się bowiem, jak twierdzi Daniel-Ange, że mimo dużych chęci, trudno jest właściwie określić, co jest powodem takiej właśnie orientacji. Niemniej nauczanie Daniela-Ange’a łączy się ściśle z Magisterium Kościoła, które mówi współcześnie, że psychiczna geneza homoseksualizmu „pozostaje w dużej części niewyjaśniona” (KKK 2357). Z tego powodu ważniejsze jest - zdaniem Daniela-Ange’a - koncentrowanie się na odkrywaniu własnej godności i patrzenie ku przyszłości, którą odsłania Bóg.

37 Por. Daniel-Ange, Homoseksualizm, 23-27, 31. Daniel-Ange stara się w sposób dość precyzyjny streścić toczącą się współcześnie dyskusję na temat przyczyn homoseksualizmu. W literaturze mowa jest o uwarunkowaniach biologiczno-organicznych oraz nabytych: psychologicznych, środowiskowych i społecznych (np. uwiedzenie, czy też czynniki wychowawcze, takie jak: alkoholizm ojca, więź uczuciowa z ojcem „niemęskim” dostatecznie, obojętność czy wrogość względem matki, przesadna więź uczuciowa z matką, środowisko wychowania jednopłciowe); zob. Szafrański, Homoseksualizm jako problem, 43-50. Wśród czynników, które mogą wpływać na pojawienie się pragnień homoseksualnych R. Cohen wylicza (niektóre z nich pokrywają się z tymi, które podaje Daniel-Ange): 1. dziedziczenie (odziedziczone zranienia, nierozwiązane problemy rodzinne); 2 . temperament chrakteryzujący się nadwrażliwością; 3 . zranienia heteroemocjonalne; 4. zranienia homoemocjonalne (zerwanie $\mathrm{z}$ własną tożsamością płciową spowodowane brakiem dobrej więzi emocjonalnej z rodzicem tej samej płci); 5. zranienia zadane przez rodzeństwo; 6. zranienia obrazu ciała (spowodowane np. przez ułomności fizyczne, chorobę); 7. przemoc seksualna; 8. zranienia homospołeczne (odrzucenie przez rówieśników tej samej płci); 9. zranienia kulturowe (indoktrynacja przy pomocy mediów); 10. inne czynniki (jak np. rozwód, śmierć rodzica); zob. Cohen, Gdy twoje dziecko, 77-84; zob. także: Kongregacja ds. Wychowania Katolickiego, Wytyczne wychowawcze, 102, gdzie jest mowa o tym, że zadaniem rodziny i wychowawcy jest odnalezienie przyczyn homoseksualizmu wychowanka, oraz gdzie zostały wymienione podobne możliwe przyczyny: czynniki fizjologiczne, czynniki psychiczne, niewłaściwe wychowanie, brak normalnego rozwoju seksualnego, zaciągnięte nawyki, złe przykłady i inne; przy ocenie zaś należy uwzględnić takie czynniki, jak: „brak uczucia, niedojrzałość, obsesyjne nawyki, deprawacja obyczajowa, swoboda widowisk i publikacji". Zob. na ten temat również: Komisja ds. Społecznych Episkopatu Anglii i Walii, „Wprowadzenie do opieki duszpasterskiej”, 175-176. 


\section{Ku wyjściu z impasu i dążeniu do pełni miłości}

Towarzyszący duchowo może poruszyć ważną kwestię, czy homoseksualizm rzeczywiście daje zadowolenie osobom praktykującym go (zmieniającym często partnerów), czy raczej rozczarowuje, nie prowadzi do spełnienia w miłości. Z samej natury bowiem miłość homoseksualna wyklucza rodzicielstwo, nie jest płodna ${ }^{38}$. Jak słusznie zauważa Daniel-Ange, w miłości homoseksualnej człowiek gra jakąśs nie swoją rolę i stopniowo przestaje być sobą. Świadectwo o tym dają niektórzy homoseksualiści, wyznając, że mają poczucie działania wbrew naturze. Wcześniej czy później - jeśli człowiek jest szczery - do tego wniosku właśnie dochodzi; i ważne jest tu, by się nie wstydzić przyznać do takich odczuć. W tym kontekście Daniel-Ange prosi i przestrzega te osoby o skłonnościach homoseksualnych, które nie podjęły jeszcze takich czynów, by na tę drogę nie wchodziły, gdyż akty te w dramatyczny sposób uzależniają. Rany w tym względzie, które zapisują się w ludzkiej świadomości i podświadomości, może uleczyć skutecznie jedynie Bóg. Dlatego takim osobom trzeba pomóc dostrzec, że istnieje szczęście pełniejsze i bardziej owocne, że można się na nie otworzyć już tutaj na ziemi; jego źródłem jest Bóg i spełniać się ono będzie $\mathrm{w}$ pełni we wspólnocie zbawionych w niebie ${ }^{39}$. Daniel-Ange delikatnie odnosi się do bólu egzystencjalnego osoby homoseksualnej, ale jednocześnie z tym bólem jej nie zostawia, ukierunkowując jej myślenie na Bożą prawdę - na pełną nadziei perspektywę nowego życia w Jezusie Chrystusie.

Potrzebne jest także umocnienie Bożą łaską słabej ludzkiej woli, odrzucenie pogardy względem siebie i uznanie, że wciąż przecież posiada się nie do końca ograniczoną wolę. Nie można zatem uznać się za człowieka całkowicie bezwolnego. Popędy nie są przecież niekontrolowalne i można nad nimi zapanowaćt ${ }^{40}$. Można wyjść z opresji obronną ręką, ale ważne jest, by tego rzeczywiście chcieć, by otworzyć się na mądre rady. Daniel-Ange pragnie „dowartościować” wolę człowieka; uczy w ten sposób odpowiedzialności za czyny, uszanowania własnej godności, prowadzi do

38 Czyny homoseksualne nie są zgodne z biologicznym przeznaczeniem narządów płciowych człowieka; zob. Klak, Osoba homoseksualna w Kościele, 26; por. Daniel-Ange, Homoseksualizm, 34-35.

39 Por. Daniel-Ange, Homoseksualizm, 36-38, 46.

40 Por. Daniel-Ange, Homoseksualizm, 39, 52. Przekonanie, że „homoseksualista zawsze będzie homoseksualistą" jest - jak twierdzi Lawrence Hatterer - destruktywnym mitem; z jego bowiem udokumentowanej dziesięcioletniej pracy terapeutycznej wynika, że homoseksualiści mogą się zmienić; podobne doświadczenie w pracy leczenia uleczalnych homoseksualistów mieli tacy psychiatrzy, jak: Samuel B. Hadden, Lionel Ovesey, Charles Socarides, Harold Lief, Irving Bieber; zob. Homoseksualizm i nadzieja, 21. Trzeba także dodać, że również i wewnątrz Kościoła pojawiają się głosy, że „leczenie psychiatryczne czy poradnictwo psychologiczne absolutnie nie jest potwierdzonym «lekarstwem» na kondycję homoseksualną. W wielu wypadkach jest to frustrujące doświadczenie [...]" (Komisja ds. Społecznych Episkopatu Anglii i Walii, „Wprowadzenie do opieki duszpasterskiej”, 184). Daniel-Ange nie podejmuje dyskusji z takimi poglądami i proponuje - jak wspomniano - tym, którzy nie akceptują swojej homoseksualności, drogę duchowej pielgrzymki ku Bogu. 
prawdziwej wolności ${ }^{41}$. Zmianie myślenia winno zatem towarzyszyć podjęcie decyzji połączonej z determinacją - by to nie ciało górowało nad duszą, ale dusza nad ciałem. Potrzebne jest podjęcie się świadomego życia duchowego ${ }^{42}$.

Niezbędne jest również wejście na drogę oczyszczenia chorej wyobraźni, zranionej pamięci, wspomnień. Droga ta jest łatwiejsza, jeśli jakieś rany były zadane jedynie w wyobraźni; trudniej jest, gdy pewne obrazy seksualnych aktów zostały usłyszane albo obejrzane; najtrudniej jest wówczas, gdy zostały one przeżyte osobiście. Daniel-Ange stwierdza, że największy dramat (wręcz zbrodnia) dokonuje się wtedy, gdy dotyczy to osoby nieletniej. Wówczas można mówić o możliwych śmiertelnych wręcz zranieniach, zarówno w strukturze emocjonalnej, psychicznej ${ }^{43}$, jak i duchowej.

$\mathrm{Na}$ drodze życia duchowego potrzebne jest podjęcie całościowego działania i w pewnym sensie - toczenia batalii „nie wprost”; koncentrowanie się nie na problemie homoseksualizmu, ale na wszystkich pozytywnych cechach swojej osobowości - w taki sposób, by je wzmacniać. Może to być realizowane na różne sposoby w świadomej służbie Bogu i ludziom (np. w pracy charytatywnej, intelektualnej, zawodowej, społecznej). Dostrzeżenie w sobie dobra jest nieodzowne: pomaga w rozwijaniu szlachetnych postaw, a tym samym w osobowym spełnianiu się zarówno na płaszczyźnie ludzkiej, jak i duchowej ${ }^{44}$.

Wielką siłę w wychodzeniu $\mathrm{z}$ trudności może przynieść wzmocnienie pragnienia poznania, kim naprawdę jest Bog - że jest On Miłością, której obrazem jest rodzina otwarta na nowe życie (ojciec i matka, i dziecko). Trzeba starać się rozbudzić chęć zaspokojenia wszelkich swoich emocjonalnych głodów: w relacji z Bogiem (gdy ktoś przeżywa brak miłości ze strony ojca); z Maryją - gdy ktoś przeżywa brak miłości ze strony matki. Daniel Ange uczy, że Matka Boża formuje na nowo zwłaszcza seksualność zniekształconą ${ }^{45}$, kształtuje właściwy obraz kobiecości i prowadzi miłość człowieka we właściwym kierunku ${ }^{46}$.

41 Omawiany autor podaje czternaście konkretnych rad, które mogą pomóc tym homoseksualistom, którzy nie akceptują swojej orientacji; zapisał je - hasłowo - w śródtytułach książki (każdą z nich rozwija w tekście); warto przytoczyć tutaj niniejsze sentencje, są nimi: 1. „Nie ograniczaj się do swego homoseksualizmu. Nie pozwól, by umniejszał twą wartość w twoich oczach”; 2. „Być darem dla innych. Stawać się innym”; 3. „Żyć w przyjaźni, tak jak w najpiękniejszej miłości”; 4. „Wobec hipererotyzmu twój superheroizm”; 5. „Pragnienie równowagi”; 6. „Wzmocnić siłę woli, opanować wyobraźnię”; 7. „Otwórz się na piękno inności”; 8. „Znaleźć swą oazę”; 9. „Poszukaj kogoś, kto cię nie opuści, kto będzie twoim towarzyszem”; 10. „Proś Swego Boga. Pozwól mu działac”; 11. „Żyj od przebaczenie do przebaczenia”; 12. „Kochaj prawdziwie swe ciało”; 13. „Odkryj kim jest Bóg”; 14. „Odszukaj Ojca, pokochaj Syna, zaufaj Maryi”; zob. Daniel-Ange, Homoseksualizm, 42-56.

42 Daniel-Ange, Homoseksualizm, 35, 47.

43 Dlatego Daniel-Ange (Homoseksualizm, 38-39) wzywa nas do wielkiej odpowiedzialności za siebie oraz za innych, szczególnie za najmłodszych.

44 Daniel-Ange, Homoseksualizm, 42, 58.

45 Daniel-Ange, Wstań! List do młodych, 50.

Daniel-Ange, Homoseksualizm, 54-56. 
$\mathrm{Na}$ drodze duchowego wzrostu istotne są zatem relacje $\mathrm{z}$ innymi - na gruncie wiary więź z Bogiem (motywacja religijna), a na gruncie społecznym rozmawianie z innymi, tworzenie zdrowych i czystych przyjaźni (szczególnie z osobami innej płci). Wszystko to służy temu, by nie zamykać się w samotności swoich myśli. W ten sposób będzie się stopniowo „poszerzać ta sfera życia, w której się nie jest homoseksualistą" ${ }^{47}$. Należy jednak zwrócić uwagę na to, by w relacjach z osobami tej samej płci wygasić interakcje seksualne. Jest to czasem długotrwały proces, naznaczony wysiłkiem, a jego istotą jest pozwolenie, by te relacje zostały przemienione miłością nadprzyrodzoną, by z egoistycznych stawały się czyste, bezinteresowne, naznaczone wolnością dzieci Bożych. Dlatego wielką pomocą jest znalezienie dla siebie wspólnoty wzrastania w wierze, sui generis szkoły życia, która byłaby miejscem wzajemnej akceptacji, służby, stawania się osobą coraz bardziej dojrzałą ${ }^{48}$. Stąd nie należy kierować się ani wyobraźnią, ani emocjami; nie należy ani uciekać w przeszłość, ani wybiegać w przyszłość. Trzeba żyć świadomie chwilą obecną, mając przed oczami konkretny plan spożytkowania życia. W poznawaniu ludzi i świata potrzebne jest kierowanie uwagi przede wszystkim na wszystko to, „co jest inne” (np. świat wewnętrzny dziewcząt - gdy ktoś jest chłopakiem; świat wewnętrzny chłopców - gdy ktoś jest dziewczyną), na to co nas odróżnia od świata ${ }^{49}$.

Daniel-Ange wskazuje wyraźnie, że ostatecznym źródłem pomocy jest Stwórca i Zbawiciel, Trójjedyny Bóg - Ojciec, Jezus Chrystus (Jego Eucharystyczne Ciało i Krew) i Duch Święty. Psychologia może służyć pomocą, ale w pewnym momencie i ona nie wystarcza. Dlatego nic nie zastąpi skierowanej do Boga osobistej prośby o pomoc - modlitwy naznaczonej dziecięcą ufnością i poddaniem się Jego woli do końca. Wyrażone w ten sposób pragnienie zmiany prowadzi ku odzyskaniu w Bogu wewnętrznej równowagi ${ }^{50}$. Szczególnym źródłem pomocy jest zatem - według Daniela-Ange’a - życie sakramentalne, które tworzy głęboką więź pomiędzy człowiekiem a osobą Jezusa Chrystusa: spowiedź (nazwana przez naszego belgijskiego zakonnika „Sakramentem Szczerości”) oraz Eucharystia („Sakrament Miłości”). Sakramenty te wprowadzają człowieka, który żałuje za popełnione złe czyny, w doświadczenie Bożego przebaczenia. Z rany zadanej Sercu Boga wypływa Jego miłosierna Miłość, która daje nadzieję i siłę, by wybudować swoje życie na nowo, będąc pojednanym z Bogiem, z ludźmi oraz z sobą samym. Sakrament pokuty i pojednania jest doświadczeniem stwórczego działania Boga - przyjęciem od Niego łaski

47 Zob. Daniel-Ange, Miłość braterska, 121. Autor uczy, zgodnie z wykładnią nauki Kościoła, że najlepszym sposobem na to, by kierować swoją seksualnością, swoimi uczuciami, jest żyć w przejrzystej czystości, a wówczas tworzą się piękne, jasne, szczere i święte przyjaźnie - siostrzane i braterskie relacje; por. KKK 2359; por. Daniel-Ange, Homoseksualizm, 43.

48 Por. Daniel-Ange, Homoseksualizm, 45-46, 49.

49 Daniel-Ange, Homoseksualizm, 47-48.

50 Daniel-Ange, Homoseksualizm, 45, 51; por. Bolewski, „Wyzywająca miłość”, 264, gdzie wspomniane jest, że modlitwa prowadzi ku „uduchowieniu” ludzkiej miłości. 
usynowienia ${ }^{51}$. Dzięki temu ludzie stają się dziećmi Bożego przebaczenia - córkami i synami Jego miłosierdzia.

Doniosłe znaczenie w leczeniu zranień ludzkiej płciowości (w tym wzroku, wyobraźni itp.) ma adoracja Najświętszego Sakramentu - kult Ciała i Krwi Pana Jezusa. Modlitwa ta oczyszcza miłość, uzdrawia wnętrze człowieka: jego serce, ciało, uczuciowość i seksualnośćc5. Dzięki adoracji Duch Jezusa rozciąga się w misteryjny sposób na całą ludzkośćs ${ }^{3}$, usuwa „schizofrenię" rozbijającą seksualność - dramatyczny rozdźwięk pomiędzy ciałem a duszą, zaistniały na skutek grzechu ${ }^{54}$. Warto tutaj zwrócić uwagę na to, jak bardzo głęboko Daniel-Ange rozumie zjednoczenie z Chrystusem w Eucharystii. Jest ona sercem życia osobistego, przeżywaniem najbardziej wzruszającej bliskości oblubieńczej ze Zbawicielem. W niej Jezus Chrystus łączy się z osobą ludzką w ,jedno ciało" (por. Mt 19,5-6), by człowiek był z Nim odtąd jednym duchem: „Ty dysponujesz Jego Ciałem, On dysponuje Twoim (1 Kor 7,4). Już nie możesz robić ze swoim ciałem, co chcesz, Twoje ciało najpierw należy do Chrystusa. Nie możesz przyjmować Jego przeczystego Ciała, a potem bezcześcić swojego! To byłaby profanacja eucharystyczna" ${ }^{55}$.

Drogę ku prawdziwej wolności należy przeżywać ze stałą świadomością, że Bóg obdarza nieskończoną miłością każdego człowieka. Należy pomagać innym, by uwierzyli w tę prawdę tak, by nawet $\mathrm{w}$ chwili największych cierpień $\mathrm{i}$ kryzysów nie zwątpili i nie odeszli od Jezusa Chrystusa. On przecież również doznał przykrości ze strony ludzi i rozumie wszystkich pogardzanych. Trzeba pomóc im ofiarować Bogu doznane cierpienia, by złączyli je z Krzyżem, który zbawia świat ${ }^{56}$. Przy tym niezbędna jest cierpliwość, czyli zgoda na działanie stopniowe, ale stanowcze. Daniel-Ange zauważa, że zarówno chęć osiągnięcia natychmiastowych efektów, jak i dokonywanie nagłych i nieprzygotowanych zmian, może mieć skutki nieprzewidziane i negatywne. Droga do pełnego uzdrowienia jest często wielomiesięczną albo nawet wieloletnią współpracą z Bożą łaską ${ }^{57}$.

Podążanie ku świętości jest możliwe nawet wówczas, gdy ktoś stale powstaje z upadków, niemniej chce się angażować, służąc Kościołowi i światu, z pokorą, w ubóstwie serca i jednocześnie ze śmiałością, czerpiąc siłę z sakramentu przebacze-

51 Daniel-Ange, Homoseksualizm, 51 oraz 52, gdzie autor podkreśla: „akt homoseksualny należy do tych rzeczy, które ranią Boże Serce i [...homoseksualistę]”.

52 Daniel-Ange, Dans tes mains, 130; por. Daniel-Ange, Homoseksualizm, 53

53 Daniel-Ange, Eucharystia. Miłość wcielona, 131.

54 Daniel-Ange, Wstań! List do młodych, 61.

55 Por. Daniel-Ange, Wstań! List do młodych, 61. Autor używa tutaj mocnego sformułowania-hiperboli „profanacja eucharystyczna” na podkreślenie tego, jak silnie jednoczy się z nami Jezus Chrystus w czasie Komunii Świętej. Słowa te nie mają wzbudzać w ludziach młodych lęku przed Eucharystią, ale wzmocnić pragnienie życia w czystości. Wspomniane wyrażenie jest tu użyte jako przenośnia. 
nia, jak i z przyjmowania Ciała Jezusa Chrystusa ${ }^{58}$. Uczy bowiem Katechizm Kościoła Katolickiego, że osoby przejawiające głęboko osadzone skłonności homoseksualne również są wezwane do wypełniania woli Bożej w swoim życiu, mogą i powinny przybliżać się - stopniowo i zdecydowanie - do chrześcijańskiej doskonałości (KKK 2358-2359), do Pełni Miłości.

„Osoba ludzka, zdaniem współczesnych uczonych, jest tak dogłębnie przeniknięta płciowością, że należy ją uznać za jeden z głównych czynników kształtujących życie człowieka. Rzeczywiście z płci wynikają cechy charakterystyczne, które w dziedzinie biologii, psychologii i duchowości, czynią osobę mężczyzną i kobietą"59. Zatem życie duchowe człowieka wiąże się implicite w jakimś sensie z jego rozwojem seksualnym. Stąd coraz częściej mówi się o duchowości kobiety i duchowości mężczyzny. Oczywiście płeć nie stanowi o istocie życia chrześcijańskiego ${ }^{60}$, niemniej tożsamość człowieka i życie duchowe związane są istotowo z byciem kobietą albo mężczyzną. Zatem gdy mowa jest o towarzyszeniu duchowym, należy zwrócić uwagę również na wymiar seksualny. W tym kontekście podjęcie przez Daniela-Ange’a tematu homoseksualizmu i cierpienia, jakie niektórzy ludzie noszą w sobie z powodu trudu określenia własnej tożsamości seksualnej, jest niezwykle wartościowe. Ludzka płciowość bowiem winna być zawsze przeżywana na sposób osobowy i zawierać się w zdolności do miłości ${ }^{61}$, dlatego musi zostać przeniknięta wymiarem nadprzyrodzonym - życiem duchowym ${ }^{62}$.

Daniel-Ange uczy, że należy stawiać sobie wysokie cele, choć nieraz wiążą się one z wielkim trudem. Jeśli jest on podjęty ze względu na Boga, staje się bardzo owocny rodzi przyszłych świętych. Do świętości zaproszeni są zarówno ci, którzy otrzymują pomoc, jak i ci, którzy pomagają. Towarzyszenie duchowe innym jest odpowiedzią na słowa Chrystusa: „I kto by przyjął jedno takie dziecko w imię moje, Mnie przyjmuje" $($ Mt 18,5).

Myśl Daniela-Ange’a na temat pomocy duchowej osobom o skłonnościach homoseksualnych opiera się mocno na Biblii, Tradycji Kościoła, znanej mu

\footnotetext{
58 Daniel-Ange, Homoseksualizm, 58-60.

59 Kongregacja Nauki Wiary, Persona humana, 1; por. Kongregacja ds. Wychowania Katolickiego, Wytyczne wychowawcze w odniesieniu do ludzkiej miłości, 101-104.

60 Por. Ga 3,28: „[...] nie ma już mężczyzny, ani kobiety, wszyscy bowiem jesteście kimś jednym w Chrystusie Jezusie".

61 Kornas-Biela, „Seksualność”, 1031.

62 Czyli życiem „według Ducha” (por. Rz 8,9).

63 Por. Daniel-Ange, Homoseksualizm, 66.
} 
literaturze, a także na świadectwach młodych ludzi, którzy dotknięci zostali pytaniem związanym z orientacją seksualną. Myśl ta jest teocentryczna, chrystocentryczna, kerygmatyczna, pełna chrześcijańskiej nadziei, optymizmu, entuzjazmu i radości ${ }^{64}$. Nie utożsamia „inności” osób o skłonnościach homoseksualnych z ich „naturą", tym samym - bardzo słusznie - staje w opozycji wobec często rozpowszechnianym poglądom generalizującym, że homoseksualizm przynależy do ludzkiej natury ${ }^{65}$.

Daniel-Ange patrzy na osobę ludzką całościowo; dostrzega w niej ciało powiązane z płciowością, psychikę, życie duchowe, intelekt i związaną z nim zdolność rozumowania, wolę dającą możliwość podejmowania decyzji, wyobraźnię, zmysły, uczucia, moralność, religijność, czyn, możliwość transcendowania siebie, tworzenia relacji $z$ innymi osobami (budowania wspólnoty), twórczego zaangażowania się społecznie itp. Tym samym prezentowany autor wpisuje się harmonijnie w nurt teorii wychowawczych podkreślających nieodzowność kształtowania płciowości w sposób integralny - poprzez interioryzację surowych poruszeń, nadawanie im nowych, właściwych form, we wdzięcznej wobec Stwórcy akceptacji za dar płciowości oraz seksualności (w Polsce przedstawicieli do szkoły integralnego ujmowania sfery płciowej - obok Karola Wojtyły - można zaliczyć: Józefa Augustyna, Marka Dziewieckiego, Włodzimierza Fijałkowskiego, Dorotę Kornas-Biela, Karola Meissnera, Wandę Półtawską, Jacka Pulikowskiego, Bolesława Suszkę) ${ }^{66}$.

Ciekawe jest to, że Daniel-Ange, mówiąc o duchowym wzrastaniu, nie wspomina o działaniu złych duchów, pokusach, walce duchowej, zniewoleniu, przynoszeniu ulgi poprzez egzorcyzmy czy modlitwę o uwolnienie - choć przecież w swoich publikacjach nie unika tego tematu ${ }^{67}$. Dlaczego tak zatem czyni? Czy robi to celowo? Wydaje się, że temat ten pozostaje przez niego nieomówiony, gdyż pragnie on koncentrować osoby zagubione przede wszystkim na Dobru - na Trójjedynym Bogu, Matce Najświętszej, na miłości miłosiernej, na Bożym przebaczeniu. Nie chce w żaden sposób przestraszyć tych, którzy już i tak doznali wielu duchowych ran w swoim życiu. Koncentruje się zaś na tworzeniu środowiska wspierającego tych, którzy duchowo walczą o swoją godność, o czystość, o wiarę.

Wobec zdeprawowania seksualności, sprostytuowania miłości - jak pisze Daniel-Ange - nadzieją napawa fakt gromadzenia się młodych o różnej przynależności religijnej i z różnych krajów, którzy publicznie deklarują pragnienie życia w czystości przedmałżeńskiej, a po ślubie w wierności małżonkowi. Walka o czystość jest walką o ludzkie szczęście. Czystość bowiem prowadzi do prawdziwej radości, powiązanej

\footnotetext{
64 Zgodnie z zaleceniami Kościoła, by duszpasterze działali z cierpliwością i dobrocią, przy jednoczesnym nieunieważnianiu Bożych przykazań (Kongregacja Nauki Wiary, Persona humana, 10).

65 Por. Prusak, „Homoseksualizm z perspektywy Kościoła”, 31.

66 Kornas-Biela, „Seksualność”, 1041.

67 Zob. Daniel-Ange, Le Renouveau, printemps de l'Église, 138-141.
} 
silnie z wewnętrzną wolnością człowieka ${ }^{68}$. Jest drogą ku tworzeniu harmonii pomiędzy miłością, życiem a ciałem, ku kontemplacji Boga (por. Mt 5,8). Szczególnie pomocna dla ludzi jest w tym względzie Maryja - Matka Pięknej Miłości ${ }^{69}$.

Głos Daniela-Ange’a jest sui generis odpowiedzią na wezwanie papieży Pawła VI i Jana Pawła II, by tworzyć klimat sprzyjający czystości ${ }^{70}$, by budować kulturę życia, by nie odrywać wiary chrześcijańskiej od wymogów etycznych, by kształtować sumienie ${ }^{71}$. Współgra również z nauczaniem papieża Benedykta XVI, który dostrzegał silny związek między całym kosmosem a Eucharystią, pomiędzy stworzeniem a „nowym stworzeniem” zapoczątkowanym w zmartwychwstaniu Chrystusa ${ }^{72}$. Myśl Daniela-Ange’a łączy się harmonijnie również i z troską papieża Franciszka, by rozmawiać z młodzieżą o ich problemach - również tych związanych $\mathrm{z}$ seksualnością, z tożsamością kobiety i mężczyzny, z homoseksualizmem - by pomóc im odnaleźć uzdrowienie $\mathrm{z}$ ran wyrytych $\mathrm{w}$ ich duszach przez doznane ciosy, porażki i smutne wspomnienia, często spowodowane ich błędnymi decyzjami ${ }^{73}$, pomóc odnaleźć uzdrowienie w duchowym szczęściu spotkania Jezusa Chrystusa, w związaniu swojej osoby z Osobami Bożymi.

\section{Bibliografia}

Bartnik, C.S., Ludzka dusza, jaźń i osoba (Lublin: Standruk 2019).

Benedykt XVI, Adhortacja apostolska Sacramentum Caritatis (2007).

Bolewski, J., „Wyzywająca miłość. Teolog o homoseksualizmie”, Wyzywająca miłość. Chrześcijanie a homoseksualizm (red. K. Jabłońska - C. Gawryś) (Biblioteka „Więzi” 289; Warszawa 2013) 257-270.

Cohen, R., Gdy twoje dziecko jest gejem. Plan uzdrowienia rodziny (Kraków: Światło-Życie 2009).

Daniel-Ange, Dans tes mains le Cosmos. Lettre à un jeune prêtre ([s.1.]: Èditions du Jubilé 1986).

Daniel-Ange, Eblouissante sexualité, pourquoi te dynamiter? Gender, identité, mariage, famille, homosexualité... SOS! (Paris: Éditions du Jubilé 2014).

Daniel-Ange, Eucharystia. Miłość wcielona, wyd. 3 (Warszawa: MIC 2007).

Daniel-Ange, Homosexuel qui es-tu? Où vas-tu? (Nouan-Le-Fuzelier: Éditions des Béatitudes 1992)

Daniel-Ange, Homoseksualizm. Czym jest? Do czego prowadzi? (Kraków: Wydawnictwo M 1993). Daniel-Ange, Któż nam ukaże szczęście? Błogosławieństwa tu i teraz (Lublin: Gaudium 2009). Daniel-Ange, Le Renouveau, printemps de l'Église (Paris: Le Sarment-Fayard 1997).

\footnotetext{
68 Daniel-Ange, O radości, 186-188; idem, Święci na trzecie tysiąclecie, 44.

69 Daniel-Ange, Któż nam ukaże szczęście?, 101-104.

70 Por. Paweł VI, Encyklika Humanae vitae, 22.

71 Por. Jan Paweł II, Encyklika Evangelium vitae, 95.

72 Por. Benedykt XVI, Adhortacja apostolska Sacramentum Caritatis, 92.

73 Por. Franciszek, Posynodalna adhortacja apostolska Christus vivit, 81, 83.
} 


\section{JAN KRZYSZTOF MICZYŃSKI}

Daniel-Ange, Mai 13. Rébellion! (Langres: Èditions du Jubilé 2013).

Daniel-Ange, Miłość braterska (Warszawa: MIC 2006).

Daniel-Ange, O radości (Warszawa: Promic 2012).

Daniel-Ange, Serviteur du Très-Beau. Bonheur en crescen-Deo! (Montrouge: Èditions du Jubilé 2019).

Daniel-Ange, Święci na trzecie tysiąclecie. Dlaczego ich unicestwiać? (Warszawa: MIC 2002).

Daniel-Ange, Twoje ciało stworzone dla miłości (Poznań: W drodze 1994).

Daniel-Ange, Twoje ciało stworzone dla życia (Poznań: W drodze 1994).

Daniel-Ange, Uzdrowienie przez miłość, Barthe, G., Dzieciectwo duchowe (Kraków: Wydawnictwo M 1998).

Daniel-Ange, Wstań! List do młodych w Polsce (Lublin: Gaudium 2009).

Franciszek, Posynodalna adhortacja apostolska Christus vivit (2019).

Gałkowska-Bachanek, M., „Płeć”, Encyklopedia katolicka (red. E. Gigilewicz et al.) (Lublin: TN KUL 2011) XV, 846-847.

Homoseksualizm i nadzieja. Oświadczenie Katolickiego Stowarzyszenia Lekarzy USA (Kraków: Światło-Życie 2004).

Jabłońska, K. - Gawryś, C. (red.), Męska rozmowa. Chrześcijanie a homoseksualizm (Biblioteka „Więzi” 148; Warszawa 2003).

Jabłońska, K. - Gawryś, C. (red.), Wyzywająca miłość. Chrześcijanie a homoseksualizm (Biblioteka „Więzi” 289; Warszawa 2013).

Jan Paweł II, Encyklika Evangelium vitae (1995).

Katechizm Kościoła Katolickiego, wyd. 2 (Poznań: Pallottinum 2002) (= KKK).

Klak, M.A., Osoba homoseksualna w Kościele (Poznań: Jerozolima 2010).

Kłysz, M. (red.), Prorok Światła i Bożej Radości. Ojciec Daniel-Ange i jego życie duchowe (Lublin: Polihymnia 2019).

Komisja ds. Społecznych Episkopatu Anglii i Walii, „Wprowadzenie do opieki duszpasterskiej nad osobami homoseksualnymi” (1979), Wyzywająca miłość. Chrześcijanie a homoseksualizm (red. K. Jabłońska - C. Gawryś) (Biblioteka „Więzi” 289; Warszawa 2013) 168-187.

Kongregacja ds. Wychowania Katolickiego, Wytyczne wychowawcze w odniesieniu do ludzkiej miłości (1983).

Kongregacja Nauki Wiary, „Homosexualitatis problema. List do Biskupów Kościoła katolickiego o duszpasterstwie osób homoseksualnych (1986)", W trosce o pełnię wiary. Dokumenty Kongregacji Nauki Wiary 1966-1994 (Tarnów: Biblos 1995) 288-296.

Kongregacja Nauki Wiary, „Persona humana. Deklaracja o niektórych zagadnieniach etyki seksualnej (1975)", W trosce o petnię wiary. Dokumenty Kongregacji Nauki Wiary 1966-1994 (Tarnów: Biblos 1995) 94-106].

Kornas-Biela, D., „Seksualność”, Encyklopedia aksjologii pedagogicznej (red. K. Chałas - A. Maj) (Radom: Polwen 2016) 1031-1044.

Paweł VI, Encyklika Humanae vitae (1968).

Prusak, J., „Homoseksualizm z perspektywy Kościoła”, Męska rozmowa. Chrześcijanie a homoseksualizm (red. K. Jabłońska - C. Gawryś) (Biblioteka „Więzi” 148; Warszawa 2003) 11-33.

Szafrański, W., Homoseksualizm jako problem pastoralno-sądowy (Włocławek: [s.n.] 1983). 
„Uchwała Senatu Katolickiego Uniwersytetu Lubelskiego Jana Pawła II z dnia 26 czerwca 2008 r. w sprawie nadania tytułu doktora honoris causa KUL o. Danielowi-Ange", Ojciec Daniel-Ange. Doktor Honoris Causa Katolickiego Uniwersytetu Lubelskiego Jana Pawła II (Lublin: KUL 2009) 5. 
